\title{
Equipment Qualification in Testing the Flexural Resistance of Bended Ceramic Tiles
}

Ana Pavlovic

Researcher

Department of Industrial Engineering -

Alma Mater Studiorum University of Bologna

Italy

Francesco Ubertini

Full Professor

Department of Civil, Chemical, Environmental, and Materials Engineering -

DICAM,

Alma Mater Studiorum University of Bologna
The capability to bend in a controlled manner Grès Porcelain stoneware tiles passing by a processes of pyroplastic deformation opens up new opportunities in utilisation of this important family of ceramics. A bent tile can be used in innovative applications, such as stairs, shelves, benches and even radiators, turning this element from a simple piece of furnishing in a modern functional component. But this change in functionality requires a new and different approach to the quality control that can no longer be limited to the validation tests as specified in the regulations used for traditional ceramics (e.g. colour, porosity, hygroscopic ...).

Starting from a brief description of the first and only device devised for the verification of flexural resistance of curved tiles, this paper investigates the limitations and possibilities of use of that innovative equipment for product/process quality monitoring. Thanks to a careful modelling of its mechanism of operation, accompanied by various simulations comparing the limit cases of use, it has been possible to verify the incidence of some of the potential weaknesses of the equipment as well as to carry out a sensitivity analysis of this new tool for measure.

Keywords: Grés porcelain stoneware, flexural tests, standards, experimental test, control of quality

\section{INTRODUCTION}

Grès Porcelain stoneware is a compact, durable and economical material, representing a perfect solution in a large range of architectural applications. Obtained through the mixing of fine clays, feldspars, quartz and other natural elements refined and homogenised through atomisation, forged through high tonnage presses and baked at the highest temperatures, the fine grès porcelain represents, the most advanced qualitative expression of ceramic products.

It is manufactured in slabs of exceptional strength and compactness, suitable for the severest applications: from pavements to walls, both for interiors or exteriors.

At the same time, a multi-patented technique to manufacture special-purpose tiles, has been developed on the basis of a "pyroplastic" shaping of porcelain stoneware tiles $[1,2]$. This process is based on a proper combination of tool machining and secondary firing in an oven which allows to bend the porcelain stoneware tile (Figure 1).

Everything starts from an ordinary flat tile. On the inner side of the tile several incisions are realized using a tool machine. These grooves have to be modelled with an extreme precision, since they will serve as a guide during the bending phase. The tile is then placed on special shaped supports, of refractory material, which slide inside a roller kiln. The thermal treatment consists

Received: August 2015, Accepted: October 2015

Correspondence to: Ph.D. Eng. Ana Pavlovic

Department of Industrial Engineering - DIN

Alma Mater Studiorum, University of Bologna

E-mail: ana.pavlovic@unibo.it

doi:10.5937/fmet1602146P

(c) Faculty of Mechanical Engineering, Belgrade. All rights reserved of a second firing at a temperature below that of sintering (e.g. $1190-1200{ }^{\circ} \mathrm{C}$ ), but with a longer firing time (e.g. less than $1100^{\circ} \mathrm{C}$ ) and slower thermal rates in order to avoid heating and/or cooling ruptures [3, 4].

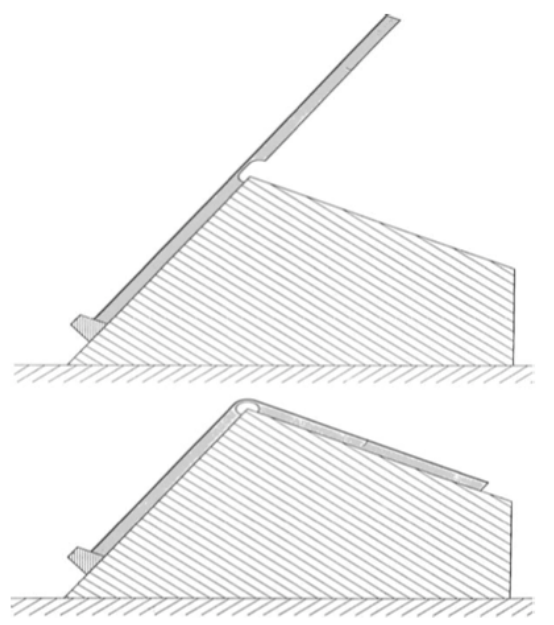

Figure 1. Pyroplastic bending process for grès porcelain stoneware tiles

When the temperature of the tile reaches a certain threshold, a viscoplasticity phenomena appears in the materials, better known as "pyroplasticity" [5]: the ceramic becomes ductile, the mass of material is deformed by gravity and is modelled (by pyroplastic deformation) couching the shape which supports it. The process ends with a slow cooling and the final exit from the oven (Figure 2).

As final results, the tile has changed its geometry assuming the curved shape of the support. By proper expedients, in both terms of process or materials, several profiles can be realized, together with various angles. 

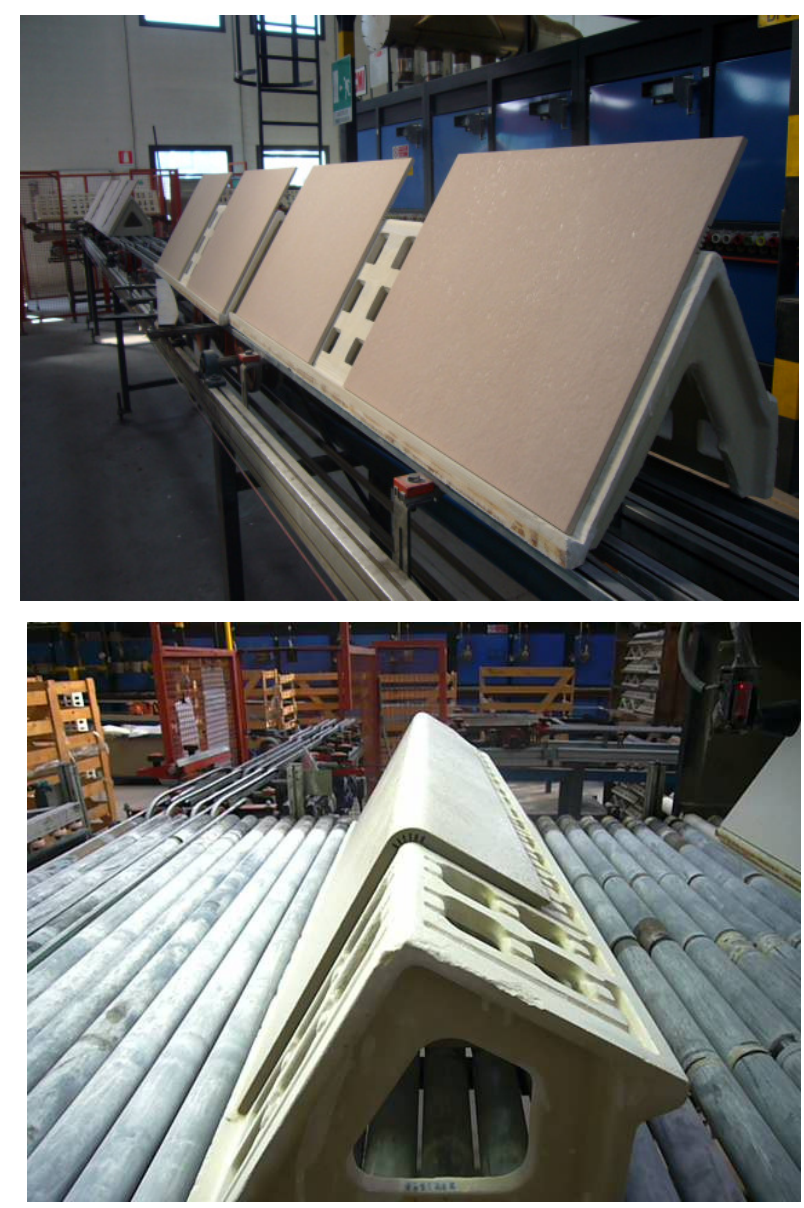

Figure 2: tiles entering in and exiting from the oven

The usability of the bending technology is huge and bended ceramic tiles can cover a wide range of applications from the world of construction and architecture [6]. A bent ceramic tile may be used, for example, to make a complete step, a skirting board connected to the floor, a shelf, a corner of the house, and much more (Figure 3).
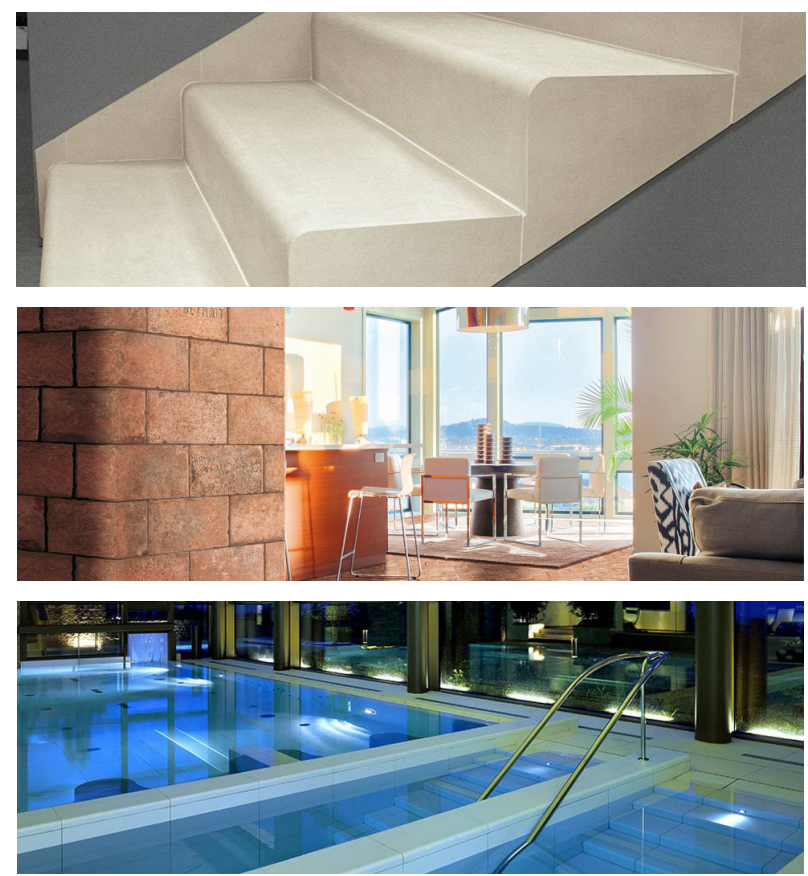

Figure 3: Advanced solutions permitted by bended tiles as stairs, walls or swimming pools
But this change in functionality also requires a new and different approach to the methodology adopted in quality control. International standards, largely used for the quality classification of traditional ceramic tiles, are too limited in the case of bended tiles. In fact, these standards do not take into account how a bended tile tends to resemble more to a mechanical component than one element of furniture. On the contrary, both the ISO 14411 [7] and 10545 [8], but also the ASTM C1161 [9] appear to refer, in their entirety, to ceramics for architectural, or decorative coating. A detailed analysis of the limits of applicability of the existing rules to the case of bended tiles is presented in [10].

The practical needs to pay a particular attention, both to the control of products and processes, combined with the almost total lack of specific standards which could be used as a valuable reference for testing bended tiles, was the central motivation for the design and realization of an innovative experimental equipment.

This device (shown in Figure 4) was presented by developers and investigators [11], as the first and only experimental apparatus, at least up to now, specifically developed for the off-line quality control of bended tiles. The test passes by the experimental measurement of the flexural strength in the most stressed point for the tile.

Adding, the validation procedure is described as very simply, effortless and precise. If all these assumptions are proved to be correct and all the methodological functionality to be saved, this equipment could be really used as an important base for the definition of a totally new testing procedure for this special family of tiles.

This paper investigates possibilities and limits in using that innovative equipment for product or process quality monitoring of bended tiles. Thanks to a careful modelling of its functional mechanisms and use of various simulations, including several limit cases of utilisation, it has been possible to verify the factual incidence of potential weaknesses as well as to carry out a sensitivity analysis of this new tool for measure.

\section{STATE OF ARTS}

This investigation starts from a preliminary analysis of common methods and equipments used in ceramics tiles for the evaluation of mechanical proprieties of resistance. In this field, ISO 10545 has to be recognized as the essential standard ruling the test methods provided for the qualifying characteristics ceramic tiles in function of their use.

This large standard consists of 17 different sections, one for each test method. Anyway, only the Part 4, on Determination of modulus of rupture and breaking strength refers to mechanical tests and proprieties. For instance, it reports the minimal thresholds of breaking and bending strength that materials have to demonstrate to be commercialized as grès porcelain stoneware.

These values can be evaluated by ordinary experiments using conventional testing machines, equipped by load cells. ISO $10545 / 4$ details all requirements for a congruent tests (tensile or flexural) as: general configuration, dimension, shape and number 
of specimens; dimension, shape and positioning of grips; application speed for loads; acquisition rate, etc.

It also specifies how to get back to mechanical proprieties from experimental measures. In particular, it is described how to determine: the force-displacement diagram; the breaking loads and displacements; the breaking strength and deformation; the stress-strain diagram. Several applications were already proposed in scientific literature [10].

In our case, considering that the new equipment aims at evaluating the flexural strength of bended tile, the section of standard referring to the determination of flexural breaking strength is the only part of interest.

In this section, a flexural test is presented. It permits the determination of the breaking load, breaking strength and modulus of rupture of a tile by applying a bending force at a specified rate to the centre of the tile, the point of application being in contact with the proper surface of the tile. A three-point flexural test is used.

According to the previous investigations [11], it is possible to confirm that ISO 10545/4 and, in particular, a three-point flexural test represents, in general, an appropriate method for measuring the mechanical flexural behaviour of Grès Porcelain stoneware even in the case of bended tiles. This test has also been already used for monitoring the process of bending of tiles [12]. It permitted, for instance, to evaluate the modifications in proprieties of the grès porcelain material related to the pyroplastic deformation in secondary firing.

As a consequence, it is certainly possible to confirm that a three-point flexural methodology represents an appropriate procedure for the off-line inspection and the quality control in the case of "incoming materials": the flat slabs (designated to be bended by pyroplasticity). At the same time, considering the sense and the strictness of this ISO procedure, it is inapplicable for testing the flexural breaking strength of tiles in the bended area.

In short, the state of arts confirms the originality of the equipment proposed and the related procedure for testing bended tiles, justifying a deeper analysis.

\section{EXPERIMENTAL EQUIPMENT}

This investigation aims, as already stated, at providing a precise procedure for qualification of the experimental apparatus (shown in Figure 4), for the quality control of bended tiles. The analysis starts a careful modelling of mechanism and movements, with special regards to the proper evaluation of conditions adopted in application of loads and constraints.

A useful starting point is [12] where this devices is presented and detailed, together with a full description of supposed working conditions. Some of these assumptions are not confirmed by the present work.

In Figure 5, a 3D sketch of device is shown, together with its main parts.

The tile is lying on the supporting table where it is blocked by the pressure exerted by the fixing lever. By a manual action of loading on the handlebar, moved by an endless screw, the operator imposes a translational adjusting to the gripping system. As a consequence, a field of pressure on the bended part of tile is applied. The load cell reads the intensity of this force. A ball joint, between the endless screw and the gripping system, reduces the effect of any misalignment.

In practice, the torsional moment on the handlebar is directly transferred to the tile by the gripping system as a contact pressure on the vertical surface and, as a consequence of this, in terms of flexural stresses in the bending zone. All mechanical parts are realized in steel. Inserts in rubber protect the ceramic tile from a direct contact with metal.
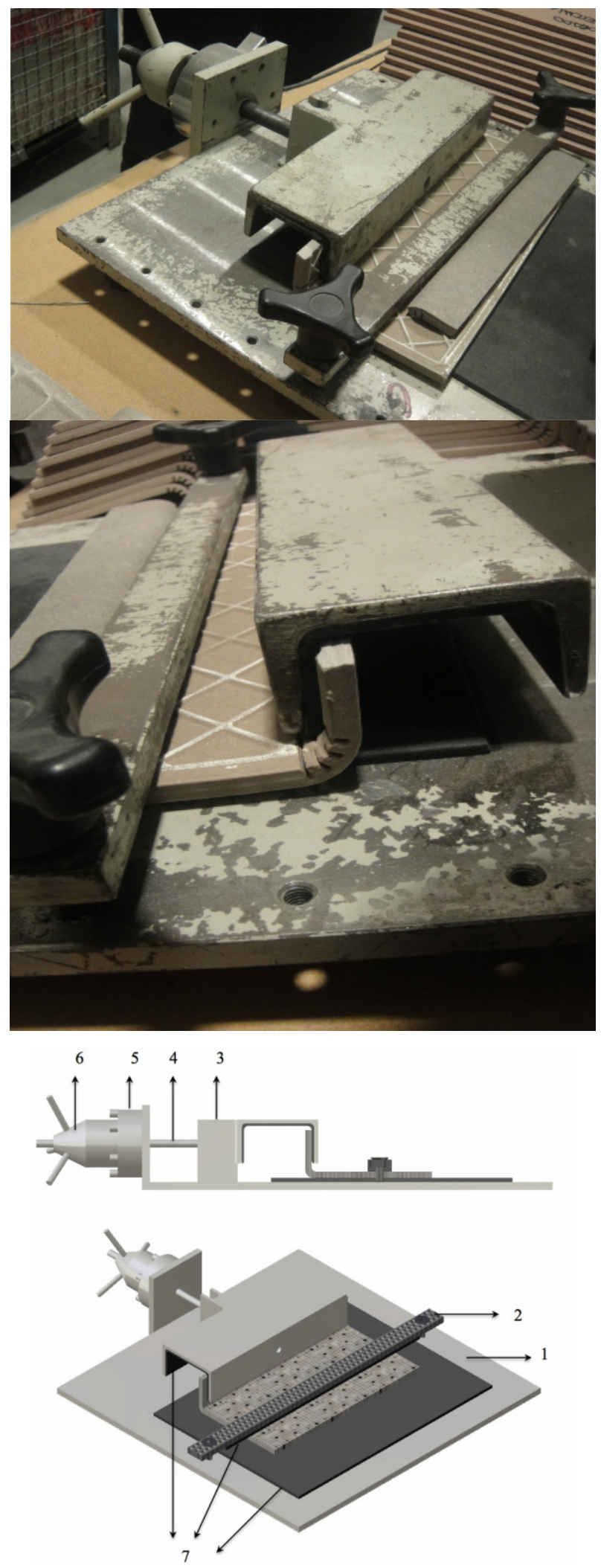

Figure 4: Equipment for testing bended tiles 


\section{METHODS}

With the aim at modelling force and constrains, several simplifications were proposed in [12].

As first step, the mechanism was considered twodimensionally. Then, instead of the ordinary 6 , only 3 degrees of freedom were considered for the tile (as rigid body): translation along and perpendicular to the table, infinitesimal rotation around the level.

The simplified system of constraints and forces is represented in Figure 5 where it is defined:

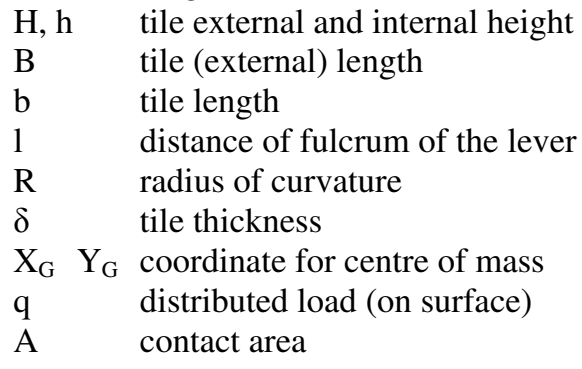

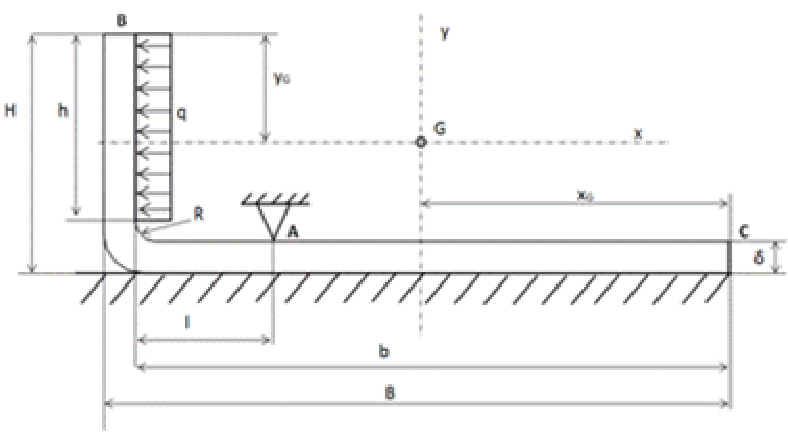

Figure 5: Basic model for loads and constrains

Reaction forces, sheers and bending moments were evaluated in accordance with this simplification and are represented in Figure 6.

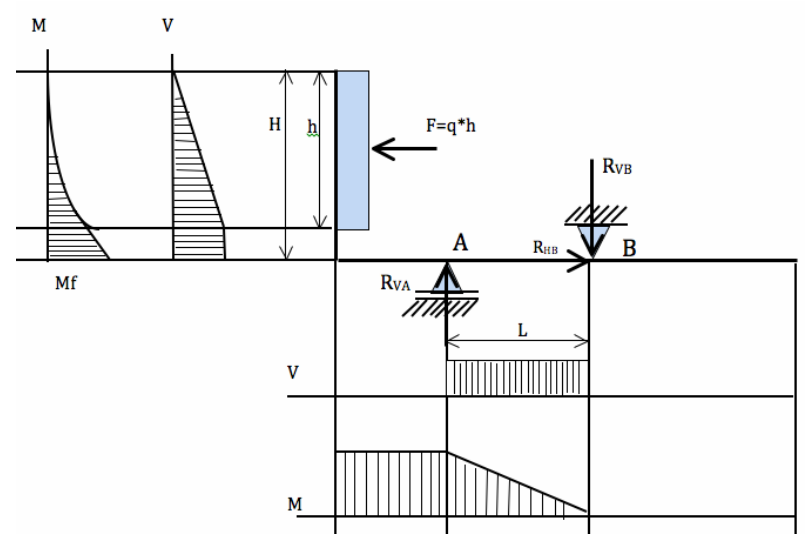

Figure 6: Simplification of loads $(F)$, reaction forces $(R)$, shears $(\mathrm{V})$ and bending moments $(\mathrm{M})$

Using this model, it was possible to theoretically estimated:

$$
\begin{gathered}
M_{f}=140 \mathrm{Nm} \\
\sigma_{\max }=\frac{M_{f}}{W_{X}} \sim 44 \mathrm{MPa}
\end{gathered}
$$

when

$$
F_{q}=4.0 k N
$$

At the same time, the proposed simplifications appear too approximate for a correct interpretation of the mechanics of testing. A deeper investigation has been possible by the application of numerical simulation techniques.

The study has been carried out on ANSYS WB14.5 simulation platform $[13,14]$, based on a Finite Element Method (FEM) and linear elasticity, following the steps:

1. definition of model geometry

2. selection of Finite Element (FE) type

3. definition of Element property

4. definition of material property

5. discretization of model in a FE mesh

6. assignment of boundary conditions

7. solving problem

8. analysis of the results

As FE a Quadratic Hexahedron - Hexa Dominant element was used, with dimension of $2 \mathrm{~mm}$, which allowed to discretize the structure by 308718 nodes and 66891 elements.

The mechanical properties of the tiles were derived from an experimental research, previously realized by the same authors (Tab. 1). It took into account how this material was undertaken, in addition to the sintering in an oven typical of ceramic processes, even a stage of second kiln firing, which is essential for the tiles bending [15].

Table 1: Mechanical properties of grés porcelain

\begin{tabular}{|c|c|c|}
\hline Property & Unit & Value \\
\hline Elastic Modulus & {$[\mathrm{GPa}]$} & 12 \\
\hline Poisson's Ration & {$[/]$} & 0,22 \\
\hline Density & {$\left[\mathrm{kg} / \mathrm{m}^{3}\right]$} & 2200 \\
\hline
\end{tabular}

A Nodal Force with the value of $4 \mathrm{kN}$ as a load condition has been chosen and applied directly on the nodes present in the contact zone. This value is the same proposed in [12] and in line with the different laboratory measurements.

At levels of constraints, the physical system has been modelled by a unidirectional support along the entire contact surface of the tile leaning on the table plus a second unidirectional support related to the pressure zone where the fixing lever acts. An additional constraint condition, applied at the level of the first support, prevents the horizontal movement of the tile making the system isostatic.

The study has been focused on the evaluation of the influence of several design aspects as: location of the lever, clamping pressure, correct positioning of the tile on table, width and symmetry of the contact area (Figure 7), and more.

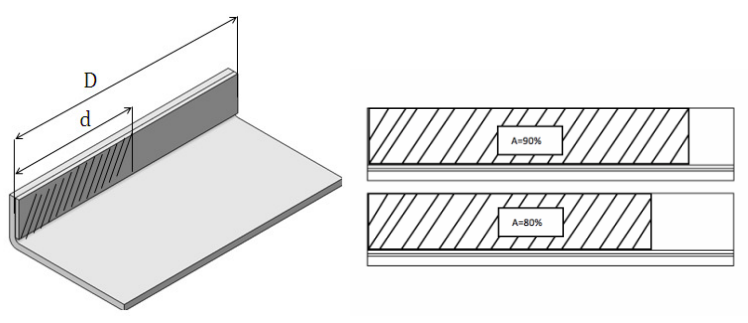

Figure 7: Asymmetry in the application load [D] 
The influence of changes in the geometric parameters of the tile such as thickness, radius of curvature, height of the curved area, was also investigated on the tensions. Although in many cases the range of variability of these factors appears to be minimal, the combined impact could lead to nonrepeatability of the test.

In summary, it has been taken into account the following parameters:
l position of the fixing lever
$\mathbf{h}_{\mathbf{q}}$ height of the contact area
d width of the contact area
$\boldsymbol{\delta}$ thickness of the tile
$\mathbf{R}$ radius of curvature of the tile

\section{COMPARATIVE ANALYSIS}

As first evidence, a not-negligible increase (10\%) in maximal stress stands out: against the $44 M P a$ evaluated with theoretical formula, the FE simulation proposes the new value of $48 M P a$. This difference could be related to an incorrect modelling of constrains and, in particular, the supporting table, acting as a distributed contact.

After comparing stress states in 21 simulations (Tab. 2 ), it becomes obvious that bending stress in the bending area is not only influenced by parameters characterizing the tile itself, such as, for example, thickness or radius of curvature (e.g. their increase reduces the maximal stress). On the contrary, clear differences appear related to specific factors of experiments, as position of tile over the device or the modality of application of load. This difference is methodologically crucial. Variability of measures that remains connected to the variability in the intrinsic parameters of the "tile product" could be considered as acceptable when comparing tiles inside homogeneous families. On the other hands, the apparent sensitivity of the measures to the specific test conditions makes the correct application of this experimental procedure extremely difficult.

Table 2: Maximal stress depending on different parameters

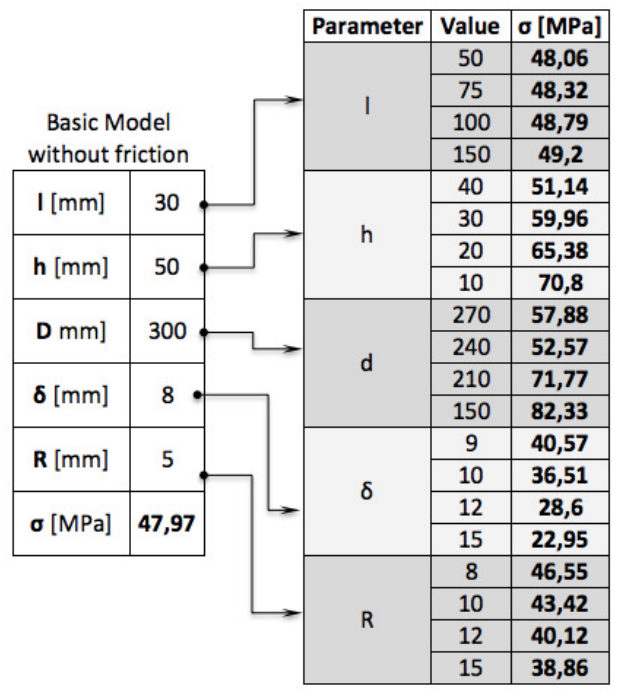

A comparative analysis on the influence of the position of the boundary conditions (represented by the fixing lever, indicated with the letter "A" in Fig. 6) demonstrates how the bending tension increases distancing this boundary from the curved area (Fig. 8).
This result prefigures that, if the same condition for tile's positioning (along $\mathrm{X}$ ) is not guaranteed, a variability in measures are expected. This inaccuracies, even if slight in absolute terms, decreases the robustness of the testing procedure suggesting changes in design with the aim at creating an control line for the correct positioning of the tile.
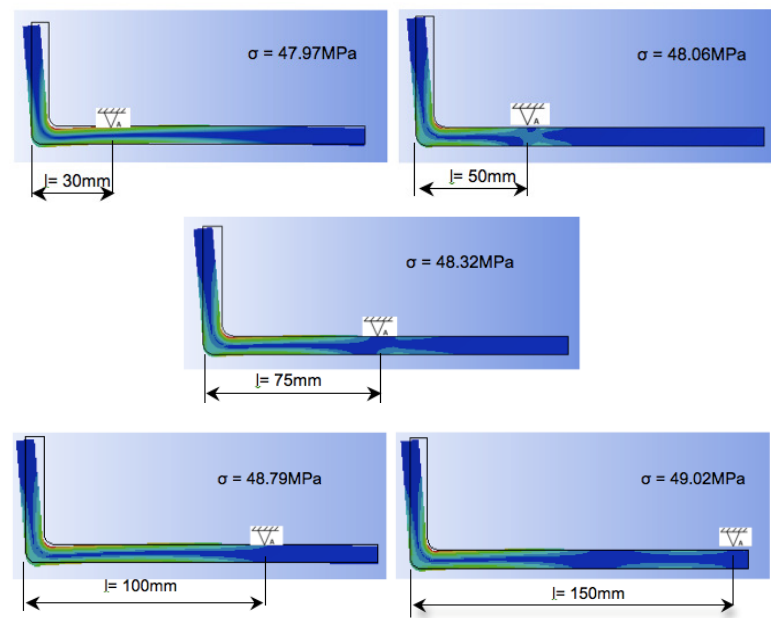

Figure 8: Influence of the position of fixing lever [l]

A further comparative study has allowed to analyse the influence on the stress state of a load transferred in a non-repetitive way. In this case, the misalignment of the tile relatively to the device due to, for example, slight rotation, has been investigated considering how it could affect dissimilar conditions for gripping. In practice this means that the width of the contact area may vary, while remaining constant the resultant force. On the contrary the direction of the force does not change and has to be always perpendicular to the contact surface since the use of the ball joint (spherical node) between the endless transmission screw and gripping system.

At the level of FEM model, it has been checked what happens in the case in which, for the same resultant force and direction of application, the contact area changes in consideration to the fact that:

- height is reduced gradually, up to $1 / 4$ of the nominal value (Fig. 9);

- width decrease asymmetrically, up to $1 / 2$ of nominal value (Fig.10).

In both cases, the simulations show a significant increase in the maximum stress, in the context of 20$30 \%$. This high variability makes it mandatory to think of remedial design procedures, such as, for example, the modification of the gripping system with the insertion of a guide able to adjust the relative positioning between the tile and gripping with extreme precision.
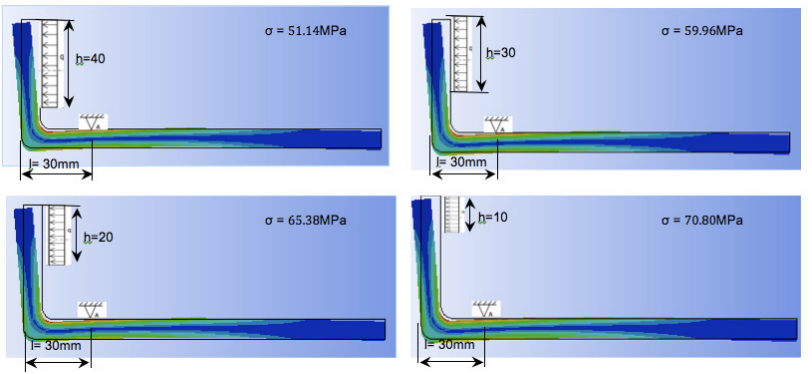

Figure 9: Influence of the position of gripping $\left[h_{q}\right]$ 

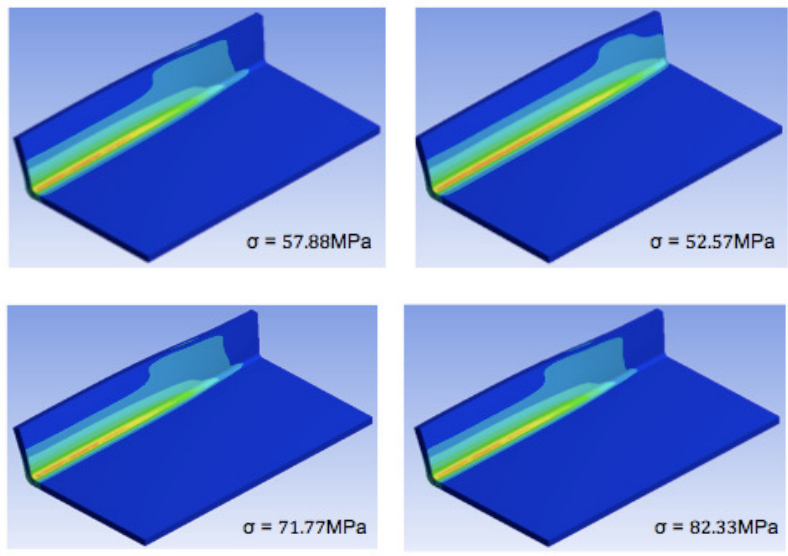

Figure 10: Influence of load asymmetry [D]

\section{BEYOND LINEARITY}

The validation of the correct functionality of this device cannot neglected all the phenomena that might dismiss the behaviour of the equipment from the idealization and, in particular, the presence of thicknesses of synthetic rubber between the tile and the supporting table, the gripping system or the fixing lever. These rubbers are used to distribute more uniformly the contact on the irregular grès surface, reducing the presence of areas of concentration of pressure and the risk of brittle fracture. But, a new model emerges, different from the theoretical one (shown in Figure 11).

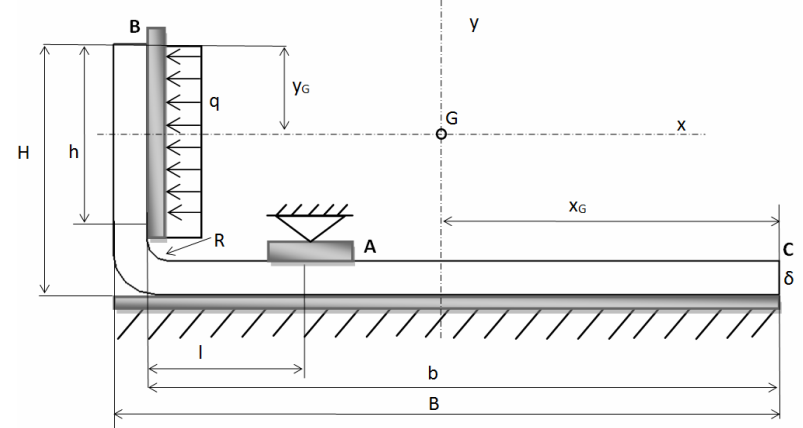

Figure 11: Evidence of contact with rubbers

In particular:

- The presence of rubber between tile and gripping system creates an indefinite contact area and, as consequence, it is complex to determine (using theory) the bending stress applied on the curved parte;

- The presents of rubber between tile and supporting table, which does not completely prevent the horizontal translation (both due to slippage of the tile, either and most relevant, for the transverse deformation of the rubber subject to shear), is likely to make the results of testing sensible on pressure intensity due to the fixing screw.

For a correct evaluation of effects of these layers on the measure, the influence of N. 3 different rubbers have been compared by FEM:

polytetrafluoroethylene [PTFE], a polymer of tetrafluoroethylene in the group of olefin, better known by the trade names of Teflon
- synthetic rubber for structural support as commercial type [indicated with the abbreviation CNR]

- ethylene-propylene [EPM], copolymers that develop long molecular saturated chains, able to make the compound suitable as a contact interface between materials of different nature.

The fundamental properties of these rubbers, quite common since their large application in industry, were investigated in several studies and available in an integrated form in [17]. In Tab. 3, only values of mechanical proprieties, interested for the present work are reported.

Table 3: Mechanical properties of common rubbers

\begin{tabular}{|c|c|c|c|c|}
\hline Property & Unit & PTFE & CNR & EPM \\
\hline $\begin{array}{c}\text { Elastic } \\
\text { Modulus }\end{array}$ & {$[\mathrm{GPa}]$} & 500 & 630 & 100 \\
\hline $\begin{array}{c}\text { Poisson's } \\
\text { Ration }\end{array}$ & {$[/]$} & 0.48 & 0.48 & 0.50 \\
\hline Density & {$\left[\mathrm{kg} / \mathrm{m}^{3}\right]$} & 2170 & 1200 & 860 \\
\hline
\end{tabular}

Beside distributing the stress in the contact area, decreasing the stress peaks at the local level and offering itself as compliant element for better transmission of forces, the rubber also introduces a phenomenon of friction that may affect the global behaviour of device. It should be also taken into consideration as, in general, the friction depends not only on the materials, but also from the applied pressure. Unfortunately, however, it has not been possible to find studies able to provide the coefficient of friction between porcelain tiles and synthetic rubber. In the absence of these data, it has been decided to investigate the problem of friction by using the measured values in the case of rubber against concrete, as described in [18] and shown in table. 4:

Table 4: Friction at different pressures

\begin{tabular}{|c|c|c|c|c|c|}
\hline Pressure & $\mathrm{MPa}$ & 5 & 10 & 20 & $>30$ \\
\hline Friction & $\mathrm{M}$ & 0.08 & 0.06 & 0.04 & 0.03 \\
\hline
\end{tabular}

At the level of discretization, wherever a contact between tile and rubber exists, a condition called as frictional asymmetrical has been applied. This condition is also indicated, sometimes, as "a passing contact" since it assumes the presence of all elements on a same surface transferring the force over target elements, all located on a second surface. This simplified choice is usually the most efficient way to model surface-tosurface contact while contraindications for it use does not appear in this specific case.

Taking into consideration the phenomenon of friction between ceramic and synthetic rubber in this way, the influences of different parameters on the stress state has been studied, as:

$\begin{array}{ll}1 & \text { the position fixing lever } \\ \mu & \text { coefficient of friction } \\ \Delta & \text { rubber thickness } \\ \mathrm{E}, \rho & \text { characteristics of rubber }\end{array}$

The maximal values of stress varying these parameters are available in Tab. 5. The influence of mechanical proprieties of rubbers are represented in Fig. 8 
Table 5: Maximal stress depending on new parameters

\begin{tabular}{|c|c|c|c|c|}
\hline \multirow{3}{*}{\multicolumn{2}{|c|}{$\begin{array}{c}\text { Basic Model } \\
\text { without friction }\end{array}$}} & Parameter & Value & $\sigma[\mathrm{MPa}]$ \\
\hline & & \multirow{4}{*}{ 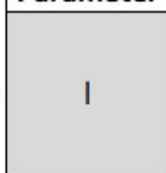 } & 50 & 48 \\
\hline & & & 75 & 48,12 \\
\hline $\mathrm{I}[\mathrm{mm}]$ & 30 & & 100 & 48,22 \\
\hline $\mathbf{h}[\mathrm{mm}]$ & 50 & & 150 & 48,99 \\
\hline $\mathrm{D}[\mathrm{mm}]$ & 300 & \multirow{3}{*}{$\mu$} & 0,06 & \multirow{3}{*}{48} \\
\hline$\delta[\mathrm{mm}]$ & 8 & & 0,04 & \\
\hline $\mathbf{R}[\mathrm{mm}]$ & 5 & & 0,03 & \\
\hline $\boldsymbol{\mu}[\mathrm{mm}]$ & 0,08 & \multirow{4}{*}{$E, \rho$} & 630 & \multirow{2}{*}{50,53} \\
\hline $\mathbf{E}[\mathrm{MPa}]$ & 500 & & 1200 & \\
\hline$\rho[\mathrm{kg} / \mathrm{m} 3]$ & 2170 & & 100 & \multirow{2}{*}{50} \\
\hline \multirow{2}{*}{\begin{tabular}{|c|}
$\boldsymbol{\Delta}[\mathrm{mm}]$ \\
$\boldsymbol{\sigma}[\mathrm{MPa}]$ \\
\end{tabular}} & 3 & & 860 & \\
\hline & \begin{tabular}{|l|}
48,02 \\
\end{tabular} & \multirow{3}{*}{$\Delta$} & 2,5 & 46,7 \\
\hline & & & 4 & 47,89 \\
\hline & & & 5 & 47,67 \\
\hline
\end{tabular}

The results make it clear that changes in the friction coefficient do not significantly modify the stress. This consideration also comes from comparing the values of maximum stress obtained in the simulations with and without contact, showing only marginal changes $(<2 \%)$. Therefore, it is useless to complicate the model introducing non-linearity as contact and friction.

Similarly, also changes in the proprieties of rubber appear to cause low alteration in the stress state $(<4 \%)$.

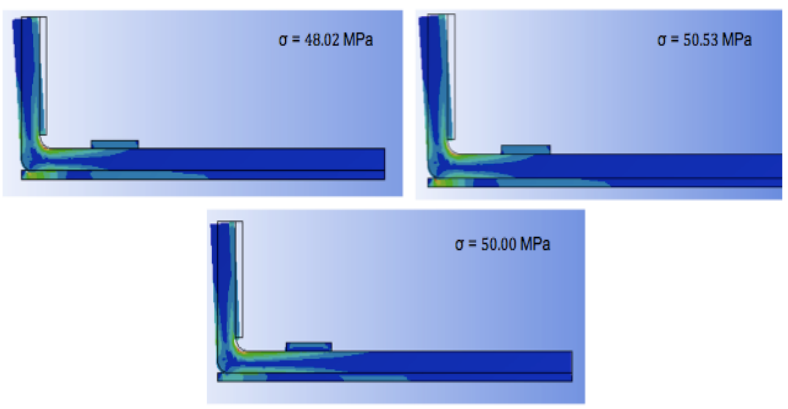

Figure 8: Influence in use of different rubbers (in clockwise direction: PTF, CNR, EPMI)

\section{CONCLUSIONS}

In the case of curved tiles we are facing entirely new functional elements, suitable for providing a response to the solutions that can be used in different occasion respect to the traditional grès porcelain. This situation makes obsolete the use of traditional standards for the determination of the mechanical characteristics of the tiles. A different methodology for testing is needed. In response, a new experimental device was designed and recently proposed with the related procedure for testing. The validation test, performed using of this specific equipment, passes by the experimental measurement of the flexural strength in the most stressed point for the tile. It is meant to represent an innovative operational mode, useful not only for the quality control of the production lot, but also to optimize the process parameters and to enable their continuous monitoring.

Considering the potential benefits, a larger investigation toward the Equipment Qualification (EQ) was preferred. The Equipment Qualification aims at verifying that the instruments must be suitable for the purpose for which they are used and that they must be appropriately calibrated. As a consequence, Equipment Qualification is gaining more and more importance in ensuring a priori the validity of results.

This study, which combines theoretical considerations and a large series of simulation moves in that direction. It allowed to estimate the portion of variability related to the experimental equipment used and to test the procedure. In particular, it allowed to demonstrate how the use of this device may be an effective strategy for monitoring the quality of products and processes provided to implement some design features and usage.

At the same time, the evident simplicity in operations is not reflected in a sufficient repeatability of the measurements. Then, its practical use could be associated with a strong variability in the measurements, up to create a worthless procedure of testing. This problem is quite common when dealing with ceramics, which, due to a combination of several factors (relative to compositions, processes ..), tends to be a material with mechanical behaviour quite unpredictable [19].

Finally, this study intends to propose itself as a proof of the advantage in using the numeric simulation as instrument for problem solving into ceramics industry. Mathematical models for predicting the behaviour of ceramic materials have been investigated for years [20]. Computer simulations have also been developed in parallel with large efforts resulting by a huge number of publications. Unfortunately accuracy in predictions continues to be a real limit for a practical application of FEM in ceramics and it is not related to computational limitations [21, 22]. Input data are often complex and algorithms not completely optimized. As consequence, direct experiments continues to represent the best way for investigating ceramics in spite of their complexity and costs $[23,24$, 25]. This is surely true when ceramics are under investigation in their processes, as sintering and pyroplasticity [26]. On the contrary, this study demonstrates how useful and practical results can be obtained when analysis is focused on ceramic product.

\section{REFERENCES}

[1] Fabbroni R.: A process for modelling ceramic tiles. Patent WO/2003/080302, Applicant Keser Diva Design S.p.a. Faenza, 2003.

[2] Conti P.P.: An Improved Method for Bending Ceramic Tiles. Patent WO/2014/064720, Applicant: Brevetti 2000 Srl, Italy Italy, 2014.

[3] Raimondo M., Zanelli C., Guariani G., Dondi M., Fabbroni R., Cortesi T.: Process of pyroplastic shaping for special-purpose porcelain stoneware tiles, Ceramic International 35, pp. 1975-1984, 2009.

[4] Fragassa C., Pavlovic A., Conti P. P.: Alteration in Mechanical Proprieties of Porcelain Passing by a Bending Process, In Proceedings of the VIII Triennial International Conference Heavy Machinery, Kraljevo 2014. 
[5] Bernardi, A. M., Demedeiros, D. S., Riella, H. G.: Pyroplasticity in Porcelain Tiles. Mater. Sci. Eng. A427, pp. 316-319, 2006.

[6] Serri, A., Luberto, L.: 23th Statistical Survey on Grès Porcelain. Sassuolo, Italy: Confindustria Ceramica 2011.

[7] EN ISO 14411: Ceramic tiles. Definitions, classification, characteristics, evaluation of conformity and marking including UNI EN ISO 13006. International Organization for Standardization, 2012.

[8] EN ISO 10545-4: Ceramic tiles - Part 4: Determination of modulus of rupture and breaking strength. International Organization for Standardization, 2014.

[9] ASTM C1161: Standard Test Method for Flexural Strength of Advanced Ceramics at Ambient Temperature, ASTM International, West Conshohocken, PA, 2013.

[10] Batista M.: Large deflections of a beam subject to three-point bending. International Journal of NonLinear Mechanics 69, pp. 84-92, 2015.

[11] Fragassa, C.: Limits in Application of International Standards to Innovative Ceramic Solutions. International Journal for Quality Research, 92, pp. 279-298, 2015.

[12] Fragassa C.: Flexural Testing Machine as an OffLine Control System for Quality Monitoring in the Production of Bended Ceramic Tiles. International Journal for Quality Research, 93, 2015

[13]ANSYS Workbench User's Guide, Release 14.5. ANSYS Inc., 2012.

[14]ANSYS Help System, Mechanical Applications Mechanical User Guide, Release 14.5, ANSYS Inc. 2012

[15] Fragassa C., Pavlovic A., Ubertini F.: Experimental Evaluation of Pyroplastic Deformation on Mechanical Properties of Grès Porcelain Stoneware, MK-14 - Research Development in Heavy Machinery 2020141, 2014.

[16] Paganelli M.: The properties of ceramic material during the firing process, Technology, Ceramic World Review n.55, 2004.

[17]CNR Technical Requirements: Apparecchi di appoggio in gomma e PTFE nelle costruzioni. Istruzioni per il calcolo e l'impiego Solutions for supports in synthetic rubber and PTFE in constructions. Instructions for calculation and use. Italian Edition N.161, CNR 10018/87. Italian National Council of Research, Roma, 2009.

[18] Paolacci F.: Design of Pre-compressed Reinforced Concrete Beams in Italian. Roma, Italy: Academia Universa Press 2010.

[19] Paganelli M.: Understanding Ceramic Material Behaviour During Rapid Heat Treatments, Ceramic Industry, 2014.

[20] Imaoka S.: Analysing Viscoelastic Materials, ANSYS Advantage, Volume II, Issue 4, 2008
[21] Fragassa C.: Methodological details in modelling the viscoelastic response of ceramic materials by commercial Finite Elements codes. FME Translations, Vol. 4 N. 1, Faculty of Mechanical Engineering, University of Belgrade, 2016.

[22] Sighinolfi D.: Experimental Study of Deformations and State of Tension in Traditional Ceramic Materials, Ceramic Materials, 63, 2, 2011, 226-232

[23] Bene P., Berardo D.: Numerical-experimental method to study the viscosity behaviour of ceramic materials, Journal of European Ceramic Society 34, pp. 2617-2622, 2014.

[24]Zmindák M., Riecky D., Dudinský M.: Finite element analysis of viscoelastic composite solids, modelling of mechanical and mechatronic systems. In Proceeding of the 4th International Conference, Faculty of Mechanical engineering, Technical Univerity of Kosice, Slovak Republic, 2011.

[25] Wolff M. F. H., Salikov V., Antonyuk S., Heinrich S., Schneider G. A.: Three-dimensional discrete element modelling of micromechanical bending tests of ceramic-polymer composite materials, Powder Technology 248 2013 77-83

[26]Fernanda M., et al.: Parameter Estimation of Viscoelastic Materials: A Test Case with Different Optimization Strategies. Numerical Analysis and Applied Mathematics. American Institute of Physics. Conf. Proc. 1389, pp. 771-774, 2011.

\section{ВАЛИДАЦИЈА ОПРЕМЕ ПРИ ИСПИТИВАҢУ ОТПОРНОСТИ НА САВИЈАҢЕ САВИЈЕНИХ КЕРАМИЧКИХ ПЛОЧИЦА}

\section{А. Павловић, Ф. Убертини}

Контролисана могућност савијања грес порцеланских плочица које се излажу процесу полипропиленске деформације отвара нове могућности примене ове значајне фамилије керамичких предмета. Савијена порцеланска плочица може да има мноштво иновативних примена. Може да се користи за степенице, полице, клупе, па чак и за радијаторе, чиме се од једноставног елемента за опремање простора претвара у функционалну компоненту. Али, ова промена у функционалности захтева нов и другачији приступ контроли квалитета која више не може да се ограничава на тестове валидације прописане за класичне керамичке производе (нпр. боја, порозност, хигроскопност...).

Полазећи од кратког описа првог и јединог уређаја за верификацију отпорности на савијање савијених плочица, овај рад се бави истраживањем ограничења и могућности коришћења иновативне опреме за праћење квалитета поизвода и/или процеса. Захваљујући пажљивом моделирању механизма функционисања, уз различите симулације за упоређивање граничних случајева коришћења, било је могуће верификовати неке потенцијалне слабости опреме као и извршити анализу осетљивости овог новог алата за обављање мерења. 